\title{
The Effect of Education Expenditure on Per Capita GDP in Developing Countries
}

\author{
Elizabeth N. Appiah ${ }^{1}$ \\ ${ }^{1}$ Department of Economics, Marketing and Services, Faculty of Business Administration, Pentecost University \\ College, Accra, Ghana \\ Correspondence: Elizabeth N. Appiah, Department of Economics, Marketing and Services, Faculty of Business \\ Administration, Pentecost University, Accra, Ghana. Tel: 233-2408-13998. E-mail: appiahg@gmail.com
}

Received: July 21, 2017

doi:10.5539/ijef.v9n10p136
Accepted: August 16, 2017

Online Published: September 10, 2017

URL: https://doi.org/10.5539/ijef.v9n10p136

\begin{abstract}
Is further public and private investment in education warranted in developing countries that is economically efficient? Does an increase in education expenditure, generate a positive impact on per capita GDP in developing countries? If so, is the impact different from that of Sub-Saharan African (SSA) countries? Education is one of the key factors of promoting economic growth because of its role in enhancing human capital thus productivity. However, adverse macroeconomic conditions and increased competition for scarce public funds have reduced governments' capacity to expand education expenditure to improve labor productivity. I use the 'system' GMM estimator to estimate the effect of an increase in education expenditure on per capita GDP. The uniqueness of this paper is that unlike other studies where only one country or region is considered, this paper examines the impact of increased spending on education on per capita GDP in developing countries. The findings indicate that expansion in education expenditure in developing countries affects per per capita GDP positively, and the effect is not different from that of SSA countries.
\end{abstract}

Keywords: education expenditure, gross enrollment rate, per capita GDP, human capital

\section{Introduction}

Education is a strategic part of any nation's functions because it determines the kind of jobs obtained, the amount of money earned and lifelong economic well-being. It is also the principal instrument for preparing an individual for later professional training, adjusting to his/her environment, and also a foundation of good citizenship. Therefore, to deny any individual the opportunity for education implies denying, not only the individual to succeed, but also denying the country the expected tax revenues and economic growth. The effects of education on economic growth as relevant to human capital in a certain region or an individual country has been found in prior research. But thus far, there have not been any attempts to examine the effects of education expenditure on per capita GDP in developing countries, and whether the effects differ from that of SSA countries.

Developing countries are changing from being primarily agricultural dependent countries to service, conceptual, and knowledge-based industries which are vital for sustainable development and economic growth. However, they are handicapped because of financial constraint to cope with the rising population, and education policies. Therefore, for developing countries to improve their per capita GDP, they must first improve their productivity which can be attained through human capital. One of the key factors that can help to achieve the needed human capital is by investing in quality education. Quality education is equipping students with the needed skills for employment, not merely being enrolled in school. Consequently, it is decisive for governments in developing countries to make education one of their top priorities. While many countries in the developing world have attained universal primary education, there are still some countries; particularly, in Africa and Asia that have not, despite the United Nations Education for All (EFA) goal that was established in 2000. This paper contributes to the literature in that, I estimate a dynamic panel model where I interact the impact of education expenditure on per capita GDP in developing countries, and contrast the impact with that of Sub-Saharan African (SSA) countries' average. My empirical analyses utilize a panel data of 139 countries over the period 1975-2015. I use the 'system' General Method of Moments (GMM) estimator proposed by Blundell and Bond (1998) to analyze my data. I find that this approach may well provide better understanding about the effect of investment in education on economic growth model for policy change in the sample under-study. 
My findings show that an investment in education impact per capita GDP positively for all developing countries; however, the magnitude of the impact when I consider developing countries average is slightly higher than that of SSA country's average. My results are robust, when I consider the endogeneity of an investment in education and per capita GDP, and control for labor force participation and exports. The rest of the paper is as follows: Section 2 presents a brief background of the study. Section 3 presents the theoretical framework, and describes the data and variables. Section 4 discusses the method used in analyzing the data. Section 5 presents the empirical results, and Section 6 concludes.

\section{Background}

Following the birth of "human capital" theory by Schultz, Mincer, Friedman, and Becker in the twentieth century, the importance of education in economic development has been acknowledged in the development literature (Psacharopoulos \& Maureen, 1985; Appiah \& McMahon, 2002; Schultz, 1999) among others. Most of these studies highlighted on the complementary relationship between human capital and physical capital, noting how human capital indirect effects can affect economic growth. Psacharopoulos found estimates of education's contribution to economic growth in 29 developing countries ranging from less than $1 \%$ in Mexico to $23 \%$ in Ghana. The works of Schultz among others, led to a series of growth study, which points to education's contribution to economic growth of developed economies. Schultz (1961) advice to developing countries is that policy that will help them to achieve economic growth is an investment in human beings. Other studies have estimated the private rate of returns to investment in education (Becker, 1964: Mincer, 1974).

Apart from education's contribution to sustained economic growth, education, like health, is a consumption good whose acquisition directly contributes to people's well-being. For this reason, the United Nations Development Program (UNDP) uses education as one of the components of its Human Development Index (HDI). Motivated in part by this observation, findings from several studies focusing on education and national development suggest that education is a key to delivering the knowledge requirements for economic development (McMahon \& Oketch 2013; Keller, 2006; Hanushek \& kimko, 2000; Schultz, 1999). These studies have shown that sustainable development in any economy depends on the availability of skilled labor force whose contribution to increased labor productivity and long-term economic growth are essential for poverty reduction and longevity. In many developing countries, the role of education, particularly, higher education on economic development remains uncertain, because it is seen by some people as something good to have, but not necessarily a preparation towards economic growth. In addition to knowing the effects of education on economic development, it may be necessary for governments in Africa know what level of education (primary, secondary, or higher education) needs to be improved.

Despite the known benefits of investment in education to individuals and the nation, the sector is in crisis throughout the developing world. Many developing countries, especially in SSA spend more resources in education, particularly, in higher education and produce more graduates each year. But are the resources that go into producing these graduates efficient in terms of quality of the education needed to enhance labor productivity? Moreover, many pupils in developing countries are poor and are from rural areas where there are not enough primary schools, left alone secondary schools, and where they exist, many children who do attend school receive an inadequate education. Thus, there is a need for a quality education finance policy that will ensure that pupils from lower income families are not left out. It is therefore necessary to address the types of social returns to investment in education. There are two types of such returns classified as "market" and "non-market", as well as the externalities of investment in education. Both non-market returns and the externalities of education are beyond the scope of this study.

\section{Theoretical Framework}

It is important to make some theoretical distinctions of "market and non-market" returns to investment in education's impact on economic growth. For this study, I will consider only the market or economic benefits of education on economic growth, because the estimation of the "non-market" returns is outside the scope of this study. The framework of this analysis is the established dynamic view of the economic development process, which includes a flow of new research in endogenous growth theory with empirical tests that focuses on investment in education as the key means for dissemination of new knowledge that can be used productively (Lucas, 1988). The formation of such human capital sets the stage for future growth because it extends from one generation to another.

\subsection{Market Benefits of Education}

Market benefits of education consist of private and public benefits. Private market benefit has economic significance because it enhances the productivity of the graduate on the job; thereby, is well-compensated in the 
labor market. Also, the private benefits of education include better employment prospects, higher salaries, and a greater ability to save and invest. These benefits enable them to purchase better health services, hence improved quality of life. Social or Public market benefits can in part be explained by the contribution of education to economic growth through increased employment rates, as well as increased tax revenues that benefit society.

\subsection{Private Benefits and Externalities}

The distinction between private benefits of education and externalities that benefit society and future generations are usually underestimated. These public benefits, for example, knowledge are benefits to others due to the education of prior generations, but often taken for granted when one makes private investment decisions. In such cases, government policies on education can potentially remedy market failure and raise economic well-being. This is referred to as "public goods" because they are "non-excludable and non-rivalrous" benefits shared equally by society (Mankiw, 2007; Romer, 1990). The public effects of education and their feedback on the economic growth process are explicitly addressed by McMahon (2010) and Klenow and Rodriguez-Clare (2005), as specific non-market effects of education, of which some are externalities on growth.

\section{Data and Estimation Method}

First, I describe the data used in the study. Then, I present and discuss the estimation method and procedure.

\subsection{Data}

My study covers 139 developing countries over the period 1975-2015. I use a panel data from the World Development Indicators (WDI) database from the World Bank. My dependent variable is the log of per capita GDP (in 2010 US\$). My variable of interest is total government expenditure on education (\% of government expenditure) and its impact on per capita GDP. I use education data following the literature, including Hanushek and WoBmann (2010), Jamison et al. (2008) Appiah and McMahon (2002), McMahon (2002), and Schultz (1999, 1961). All else equal, an increase in education expenditure is expected to enhance enrollment; thus, improve the stock of human capital. This can potentially increase productivity; hence, per capita GDP. It is a fact that not all developing countries have reached universal secondary education; but, the majority of them has attained universal primary education, thus, I employ both primary and secondary enrollment rates in my regressions. Educated labor force tends to be healthy because they have high-paying jobs that enable them to afford better health services, as well as to access information on better health, which improves human capital. Elevated levels of human capital improves productivity and productivity increases output all else equal, thus exports of goods \& services (annual \% growth). The table below is the summary statistics of my datasets.

Table 1. Summary statistics

\begin{tabular}{|c|c|c|c|c|c|c|c|}
\hline \multirow[t]{2}{*}{ Variable } & \multirow[t]{2}{*}{ Label } & \multicolumn{2}{|c|}{ Developing countries } & \multicolumn{2}{|c|}{$\begin{array}{c}\text { Developing countries } \\
\text { excluding SSA }\end{array}$} & \multicolumn{2}{|c|}{$\begin{array}{c}\text { Only countries in } \\
\text { Sub-Saharan Africa }\end{array}$} \\
\hline & & Mean & Std. Dev. & Mean & Std. Dev. & Mean & Std. Dev. \\
\hline Per capita GDP & gdppc & 4071.87 & 3317.36 & 5086.28 & 3160.10 & 1163.88 & 1746.81 \\
\hline Education expenditure & edex & 89.23 & 9.03 & 90.79 & 7.12 & 84.75 & 12.00 \\
\hline Total labor force & lft & 63.65 & 11.54 & 59.87 & 9.44 & 74.47 & 10.07 \\
\hline Gross primary enrollment & ger1 & 105.54 & 18.55 & 106.25 & 15.32 & 103.51 & 25.91 \\
\hline Gross secondary enrollment & ger2 & 69.65 & 26.62 & 88.83 & 17.78 & 37.61 & 21.24 \\
\hline Exports & exports & 6.34 & 14.27 & 5.16 & 9.12 & 9.72 & 20.39 \\
\hline
\end{tabular}

Note. No. of countries: all developing, 139; developing excluding SSA, 91; SSA, 48. Time: 1975- 2015. No. of observations: all developing, 406; developing excluding SSA, 301; SSA, 105. Per capita GDP data are in constant 2010 U.S. dollars. Education expenditure is total government expenditure on education (\% of government expenditure). Labor force is the proportion of the population ages 15 and older that is economically active. Gross primary education (total no. of pupils enrolled at primary level in public and private schools). Gross secondary education (total no. of pupils enrolled at the secondary level in public and private schools). Exports (annual \% growth of goods and services), aggregates based on constant 2010 U.S. dollars.

\subsection{Estimation Procedure}

I apply the Keynesian modeling framework which hypothesizes that an expansion in government spending stimulates economic growth. Although this theory has since fallen out of favor, some policy makers still believe that increases in government spending have a positive effect on economic growth; therefore, a higher level of government spending on education is a decisive determinant of economic growth in developing countries. Based on this and the neoclassical model, I specify the growth of per capita GDP equation as:

$$
Y=A F(K, L)
$$


where $Y$ represents per capita GDP; $K$ denotes capital stock as its share of per capita GDP; $L$ describes the amount of unskilled labor; and $A$ represents technology. However, due to the relationship between labor and technology represented by efficiency factor, the model is rewritten as:

$$
Y=F(K, A L)
$$

Equation 2 indicates that an increase in any one of these variables, allows me to see how it would affect economic growth. The stock of capital is an adequate investment in human capital; hence, I proxy $K$ variable with education expenditure. Therefore, education expenditure and skilled labor force can be combined to produce final goods and services according to the production function. I extend the production function in specifying the per capita GDP (y) equation to include the following:

$$
y=f\left(e d x_{i t} l f t_{i}, K_{i t}\right)
$$

where per capita GDP represented by $(\mathrm{y})$ is a function of education expenditure $\left(\mathrm{edx}_{\mathrm{it}}\right)$, labor force $(l f t)(\%$ of population $15+$ ), and $K$ is a vector of control variables and are exogenous in the regression i.e. $E\left[K_{i j} \varepsilon_{i t}\right]=0$ for all $\mathrm{j}$ and t. The variables include gross primary school enrollment $\left(e d u l_{i t}\right)$, gross secondary school enrollment $\left(e d u 2_{i t}\right)$, and export (annual \% growth). These variables have previously been found to influence economic growth. I include $Y_{t-1}$ to test for convergence hypothesis. In addition, I introduce labor force in a quadratic system to reiterate the hypothesis proposed by Schultz (1999) that the marginal effect of per capita GDP diminishes as education expenditure increases all else equal. I introduce a dummy variable for SSA countries ( $s s a)$ to capture the effect of SSA policy change in the expansion of education expenditure on per capita GDP. Specifically, I examine if the impact of investment in education on per capita GDP in SSA countries is different from that of other developing countries. From the above discussion, I estimate the equation below to investigate the impact of increased investment in education on per capita GDP using a panel of 139 countries over the period (1975-2015):

$$
\begin{gathered}
L Y_{i t}=\alpha L Y i t_{-1}+\beta_{1} e d x_{i t}+\beta_{2} l f t_{i t}+\beta_{3} l f t^{2}{ }_{i t}+\beta_{4} g e r 1_{i t}+\beta_{5} g e r 2_{i t}+\beta_{6} \operatorname{export}_{i t}+\beta_{7} s s a+\varepsilon_{i t} \\
\varepsilon_{i t}=\mu_{i t}+v_{i t}
\end{gathered}
$$

where $i$ indexes observational units and $t$ indexes time. $L Y_{i t}$ is the log of per capita GDP as a percent of GDP and $L Y_{i t-1}$ is its lagged value and $\varepsilon_{i t}$ is the stochastic error term. The rest of the variables are as defined above.

Education expenditure $\left(e d x_{i t}\right)$ and per capita GDP $\left(Y_{i t}\right)$ is assumed to be endogenous in the model, because an increase in education expenditure $(e d x)$ may cause an increase in the stock of human capital, hence a positive effect on per capita GDP, and vice versa. But the regressors may be correlated with the disturbance term $\left(\varepsilon_{\mathrm{it}}\right)$, which are the unobserved country specific fixed effects, $\mu_{i t}$ and the shocks, $v_{i t}$ as shown in Equation (4). This disturbance term is dealt with by employing the Arellano - Bond (1991) two-step difference GMM estimator designed for large - panels and small-time periods to examine the effect of education expenditures on per capita GDP. The Arrelano - Bond two-step GMM estimator uses the first-step residuals to estimate the covariance matrix of moment conditions, which will make the endogenous variables to be pre-determined, hence not correlated with the residual in equation (4). However, the presence of the lagged dependent variable, $Y_{i t-1}$ gives rise to autocorrelation. To remove the fixed country-specific effect, Arrelano - Bond applied first differencing to transform the regressors. So, Equation (4) is transformed as:

$$
\begin{aligned}
\Delta \operatorname{Lgdppc}_{i t}=\alpha \Delta \operatorname{Lgdppc}_{i t-1}+\beta_{1} \Delta e d x_{i t}+ & \beta_{2} \Delta l f t_{i t}+\beta_{3} \Delta l f t_{i t}^{2}+\beta_{4} \Delta \operatorname{ger}_{i t}+\beta_{5} \Delta g e r 2_{i t}+\beta_{6} \Delta \text { export }_{i t}+ \\
& \beta_{7} \Delta s s a+\Delta \varepsilon_{i t} \\
& \Delta \varepsilon_{i t}=\Delta \mu_{i t}+\Delta v_{i}
\end{aligned}
$$

According to Drukker (2008), a potential problem that may arise from the Arrelano - Bond difference GMM estimator is that if $E\left[X_{i j} \varepsilon_{i t}\right]=0$ for $\mathrm{j} \leq \mathrm{t}$ but allows $E\left[X_{i j} \varepsilon_{i t}\right] \neq 0$ for $\mathrm{j} \geq \mathrm{t}$, then the variables are said to be predetermined. For example, an increase in per capita GDP today caused an increase in investment in education tomorrow. Arellano and Bover (1995) pointed out that when the variables are predetermined, the lagged levels of the regressors are poor instruments for the first-differenced regressors, because the whole vector of differences of the observed $K_{\text {it }}$ cannot be included in the instrument matrix (ibid). Blundell and Bond (1998) proposed the 'system' GMM estimator developed from the work of Arrelano and Bover (1995). This approach is considered more efficient because it is supposed to alleviate the poor instruments problem by using additional moment conditions, and free it from autocorrelation. While the difference GMM estimator suffers from 'weak' instruments, the drawback of the system GMM estimator is that it uses 'too many' instruments, which also pose a problem (Hayakawa, 2007). As evidenced in Acemoglu (2005), Bobba and Coviello (2007), both difference estimator and system estimator yield different results, thus a concern of the validity of the results. The system GMM estimator; however, fits well with dynamic panel-data and thereby provides useful background for my 
study. Based on this, I use the two-step system GMM estimator, which is asymptotically efficient and robust to all kinds of heteroskedasticity to estimate a linear panel data to first estimate the effect of an increase in education expenditure on per capita GDP in developing countries in Equation (5) without the dummy variable $(s s a)$. Then, I estimate Equation (5) with the dummy variable ( $s s a)$ to examine if the effects on per capita GDP in SSA countries differ from that of other developing countries.

\subsection{Hypotheses}

I hypothesize that an increase in education expenditure $(e d x)$ improves human capital, which is proxied, labor force (lft), therefore the expected sign for labor (lft) is positive because of labor productivity. To improve the findings in the paper, I include a quadratic term for labor $\left(l f t^{2}\right)$. I then hypothesize that the sum of the marginal effect of human capital (lft) is positive. I hypothesize that education (gerl and ger2) has a positive effect on per capita GDP because of the increase in education expenditure. As labor productivity increases, it affects output positively; thus, expand the annual percentage growth of 'exports'. Therefore, I theorize 'exports' to have a positive impact on per capita GDP. I also hypothesize that the impact of an increase in education expenditure on per capita GDP of developing countries is positive, and it does not differ from that of SSA countries.

\section{Statistical Results}

First, I provide the summary statistics of the data presented in Table 1. This is followed by the analysis of the empirical results.

\subsection{Descriptive Statistics}

The summary statistics are presented in Table 1 through Table 3. The variables used include the log of per capita GDP, education expenditure, gross enrollment rates for primary education, gross enrollment rates for secondary education, labor force participation, annual export growth, and a dummy variable for SSA. Table 1 presents statistics for all developing countries, while Table 2 and Table 3 illustrate the descriptive statistics for developing countries excluding SSA countries and only SSA countries respectively. I chose primary and secondary education because the data show that many developing countries have attained primary and secondary education. The data statistics in the tables show that the proportion of government expenditure on education is somewhat lower in SSA countries than in other developing countries. As expected in SSA countries, both primary and secondary education average lag the rest of the developing countries average. This can in part be explained by the low levels of investment in education in the countries in SSA; hence, contributed to the relatively low per capita GDP in SSA countries. Nevertheless, the mean of total labor force in SSA countries is higher than the other developing countries average. Although SSA countries' labor force average higher than the rest of the developing countries, they lack the necessary human capital skills needed to enhance productivity. The mean for annual export growth is also higher for SSA countries. But this can in part be explained by the rich raw materials such as minerals, crude oil, and other natural resources, which are abundant is SSA countries. These resources are exported without adding any value, and thus explain the discouraging per capita GDP in SSA countries.

\subsection{Empirical Results}

I employ the two-step system GMM estimator to analyze my data. I choose this method because it provides relatively better estimates than the difference GMM estimator in terms of finite sample bias and root-mean-square error (rmse) as found in Bun and Windmeijer (2009). First, I analyze the parameters $\beta_{2}, \beta_{3}$ in a linear form followed by the quadratic way and the marginal effect of investment in education on per capita GDP based on the following questions:

(i) Does an increase in education expenditure have a causal impact on per capita GDP in developing countries?

The estimated values of $\alpha, \beta_{1}$ through $\beta_{7}$ are as shown in Table 5. The test statistics suggest that the null hypothesis was rejected on the basis that variation in the dependent variable cannot be explained by variation in the explanatory variables at $\rho=.01$. The test statistics also show the absence of serial correlation. I estimate the impact of education expenditure on per capita GDP in developing countries. Employing the two-step system GMM estimator, I estimate equation (5) without the dummy variable ( $s s a$ ).

I recognize that increased education expenditures did not automatically translate into higher per capita GDP. However, I believe that the more resources a country devotes to education, the larger will its education enrollment; hence, improve human capital over time, all things equal. For this reason, I use labor (lft) as a sufficient proxy for human capital, since educated workers have higher wages that will enable them to purchase health care services. Therefore, the marginal change of the parameters, $\beta_{2}$ and $\beta_{3}$ are estimated. All the variables in my regression are significant at the $1 \%$ level. The results are reported in Table 5. 
By partially differentiating equation (5), log of per capita GDP (Lgdppc) with respect to labor (lft) $\frac{\partial L g d p p c}{\partial l f t}$ in a linear form for all developing countries, the parameter $\beta_{2}$ is positive and statistically significant at $\rho=0.01$, indicating that an increase in education expenditure improves labor force, thus impact per capita GDP positively for all developing countries. However, the parameter, $\beta_{3}$ in a quadratic way turns negative $(-0.056)$ and it is significant, suggesting a diminishing rate that is consistent with the predictions by Schultz (1999).

I then calculate the marginal effect of education expenditure on per capita GDP by subtracting the calculated value of the labor force in the quadratic way from the estimate in the linear way as shown below. The calculated value is positive, suggesting that with the expansion of education expenditure, the marginal effect of education greatly influence per capita GDP in developing countries as evidenced in Ali and Jabeen (2015), and Krueger and Lindahl (2001). Therefore, this paper can potentially contribute to the understanding of the magnitude of the impact of education expenditure policies on per capita GDP. It can also inform governments in developing countries that improvement in education expenditure policy is part of the growth engine for per capita GDP.

$$
\begin{aligned}
\frac{\partial \operatorname{lgdppc}}{\partial l f t} 11.351+2(-.0 .056) \times 63.649 \\
=11.351-7.129 \\
=4.222>0
\end{aligned}
$$

Results are consistent with the findings in Appiah and McMahon (2002), where they found out that a fraction of GNP spent on education, finances about 20 percentage point increase in primary and secondary education. This in turn translates into an increase in per capita income by $2 \%$. Ozturk (2001) pointed out that no economic development is possible without education. He reiterated that a balanced education system generates individual income per capita because of the inherent labor productivity which enhances economic development. Hanushek and Kimko (2000) study proved that quality education has a tremendous effect on productivity and growth rates. Petrakis and Stamatakis (2002), and Keller (2006) find a significant relation of education at all levels and per capita GDP in developed countries and less developed countries. Also, using a cross-country data set for least developed countries and OECD economies Petrakis and Stamatakis (2002) find a link between growth and education policies, but at various levels of economic development. Their results suggest that growth of least developed countries depended more so on primary and secondary education, while growth in OECD economies depend mainly on higher education.

(ii) Is the impact of an increase in education expenditure on per capita GDP in developing countries different from that of SSA countries?

I repeat equation (5), but this time, with the dummy variable (ssa) to examine if the effect of education expenditure on per capita GDP for SSA countries differs from that of developing countries. The estimated parameter values are reported in the last column of Table 5. Again, as addressed above, I use the parameters $\beta_{2}$ and $\beta_{3}$ to examine the effect of education expenditures on per capita GDP. The value of the parameter $\beta_{2}(10.967)$ is positive and statistically significant, while that of the quadratic term, $\beta_{3}(-0.057)$ is negative and statistically significant indicating a diminished return. To evaluate the marginal change in per capita GDP with respect to lft of changes in education policy in SSA countries, I calculate the following:

$$
\begin{array}{rl}
\frac{\partial L g d p p c}{\partial l f t} 1 & 0.97+2(-.0 .057) \times 74.473 \\
= & 10.967-8.490 \\
= & 2.477>0
\end{array}
$$

My estimates show that changes in education expenditure laws improved labor productivity, thereby contributed to economic growth in SSA countries. This suggests that increases in government, education expenditures in SSA countries have a positive effect on school enrollment, thus human capital, which then impact per capita GDP positively. This is consistent with Bils and Klenow (2000), who observed that countries with more school enrollment rate recorded an improvement in labor productivity; hence, contributed to an increase in per capita income.

It is also evidenced here that education policy interventions in SSA countries have precise quantitative payoffs on per capita GDP. However, the payoffs are lower than that of the rest of developing countries. As depicted in the descriptive statistics of Tables 1 through Table 3, the mean for SSA countries primary and secondary school 
enrollment is somewhat lower than the rest of the developing countries. So, the full effect of human capital in SSA countries per capita GDP can only be assessed when the policy change in education expenditure is sustained for a longer time. This will allow systematic changes in education enrollment and labor productivity. Statistics have shown that the SSA average enrollment rate is less than the rest of developing countries average, suggesting that SSA countries spend less on education than their counterparts in developing countries. Moreover, SSA average per capita GDP $(1,163)$ in Table 3 is the lowest. This can in part be explained by the relatively low education expenditure and school enrollment. Consequently, as policy makers in SSA countries strive to improve their per capita GDP, it will be more effective if they consider education policy as a major policy that can potentially improve labor productivity.

The estimated coefficient of the dummy variable (ssa) is negative, but not significant, an indication that for SSA education expenditure has no significant effect on per capita GDP or it has a negative effect. This can partly be explained by governments giving more priority to other sectors rather than education. This undermines the positive effect of education expenditure on per capita GDP.

I now turn my attention to the other variables; primary and secondary education, and exports. The estimated value of $\frac{\partial L g d p p c}{\partial g e r 1}$ turns negative and significant, indicating that primary education is not sufficient to improve per capita GDP in developing countries. However, the estimated value of $\frac{\partial \operatorname{Lgdppc}}{\partial g \operatorname{ger} 2}$ is positive and significant, suggesting that secondary education has a positive effect on per capita GDP in developing countries. This is a clear indication that almost all developing countries have attained primary education, whereas fewer countries have reached universal secondary education. Export intensity has a favorable effect on per capita GDP. This indicates that with the expansion of education expenditure, society's labor force improves because of higher economic returns to educated workers enabling them to purchase health care services. Consequently, they are less likely to be absent from work, which improve one's human capital. Moreover, many studies have estimated a causal effect of schooling on health outcomes because educated individuals report better physical health, thus enhance a country's human capital and productivity (Amin et al., 2013). Growth in labor productivity contributes more to economic output; hence, export levels as found in developed countries.

\section{Conclusion}

This paper examines the impact of education expenditures on per capita GDP in developing countries and investigate if the impact is different from SSA countries. I use a panel data and 'system' GMM estimator to investigate if there are differences in the results of developing countries and that of SSA countries. My main results support the argument that expansion of education expenditure has a positive effect on per capita GDP. I find no significant difference in the impact of education expenditure on per capita GDP in developing countries and SSA countries. However, the magnitude of the impact is higher in developing countries than that of SSA countries. This suggests that although, SSA countries annual export growth is relatively higher than that of other developing countries, they lack the necessary human capital that can add value to their produce. It is important that they improve their level of human capital to make a significant impact on per capita GDP.

Hanushek and Wößmann (2010) observed that it is not just enrollment rate that counts for economic growth, but rather the knowledge acquired through education. Therefore, policy makers must pay more attention to the quality of education. This paper does not suggest that education is the only, or the major contributing factor of per capita GDP. There are other contributing factors, and this paper attempts to bring out the marginal effects of education on sustainable per capita GDP. Conclusions drawn from this study indicate that there is a significant positive impact of education expenditure on economic growth and it is consistent with the findings in (Ali \& Jabeen, 2015; Petrakis \& Stamatakis, 2002; Aghion et al., 2009) among others. The findings in other studies suggest that various levels of education affect per capita GDP and development outcomes differently. In effect, policy changes to increase education expenditures in developing countries have a positive impact on per capita GDP. Education improves workers' productivity, which in turn has positive effects on per capita GDP. Therefore, my study contributes to the literature because any country in the developing world can apply the findings in their policies on education expenditure. 
Table 2. 'System' GMM estimates of per capita GDP equation

\begin{tabular}{lcc}
\hline Variables & System GMMWithout the interaction term & System GMM With the interaction term \\
\hline LLgdppc & $0.9548^{* * *}$ & $0.9576^{* * *}$ \\
& $(0.000)$ & $(0.000)$ \\
edx & $0.585^{* * *}$ & $0.459^{* * *}$ \\
& $(0.000)$ & $(0.000)$ \\
$\mathrm{ft}$ & $11.351^{* * *}$ & $10.967 * *$ \\
& $(0.000)$ & $(0.000)$ \\
$\mathrm{fft}{ }^{2}$ & $-0.056^{* * *}$ & $-0.057^{* * *}$ \\
& $(0.000)$ & $(0.000)$ \\
ger1 & $-1.059^{* * *}$ & $-0.929^{* * *}$ \\
& $(0.000)$ & $(0.000)$ \\
ger2 & $0.946^{* * *}$ & $0.939^{* * *}$ \\
& $(0.000)$ & $(0.000)$ \\
export & $6.390^{* * *}$ & $6.376^{* * *}$ \\
& $(0.000)$ & $(0.000)$ \\
ssa & & -21.994 \\
& & $(0.743)$ \\
Number of observations & 406 & 406 \\
Number of countries & 139 & 139 \\
\hline
\end{tabular}

Note. $\mathrm{p}$-values in parenthesis. $*$ significance at $\beta=0.10 . * *$ significance at $\beta=0.05 . * * *$ significance at $\beta=0.01$. The null hypothesis is that the errors in the regression exhibit no serial correlation

\section{References}

Acemoglu, D., Johnson, S., Robinson, J. A., \& Yared, P. (2005). From education to democracy? The American Economic Review, 95(2), 44-99. https://doi.org/10.1257/000282805774669916

Aghion, P., Boustan, L., Hoxby, C., \& Vandenbussche, J. (2009). The causal impact of education oneconomic growth: Evidence from US. from https://scholar.harvard.edu/aghion/publications/causal-impact-education-economic-growth-evidence-us

Ali, H., \& Jabeen, A. (2015). Effects of education on economic growth: Evidence fromPakistan. American Journal of Economics, Finance and Management, 1(6), 379-585.

Amin, V., Behrman, J. R., \& Spector, T. D. (2013). Does more schooling improve health outcomes and health related behaviors? Evidence from U.K. Twins. Econ Educ Rev., 35, 134-148. https://doi.org/10.1016/j.econedurev.2013.04.004

Anonymous. (1984). The contribution of education to economic growth: International comparisons. In J. Kendrick (Ed.), International Productivity Comparisons and the Causes of the Slowdown (pp. 335-60). Ballinger for the American Enterprise Institute.

Appiah, E. N., \& McMahon, W. W. (2002). The social outcomes of education and feedbacks on growth in Africa. Journal of Development Studies, 38(4), 27-68. https://doi.org/10.1080/00220380412331322411

Arellano, M., \& Bond, S. (1991). Some tests of specification for panel data: Monte Carlo evidence and an application to employment equations. The Review of Economic Studies, 58, 277-297. https://doi.org/10.2307/2297968

Arellano, M., \& Bover, O. (1995). Another look at the instrumental variable estimation of error-components models. Journal of Econometrics, 68, 29-51. https://doi.org/10.1016/0304-4076(94)01642-D

Becker, G. (1964). Human Capital (2nd ed.). New York: Columbia University Press.

Bils, M., \& Klenow, P. (2000). Does schooling cause growth? American Economic Review, 90, 1160-1183. https://doi.org/10.1257/aer.90.5.1160

Blundell, R., \& Bond, S. (1998). Initial conditions and moment restrictions in dynamic panel-data models. Journal of Econometrics, 87, 115-143. https://doi.org/10.1016/S0304-4076(98)00009-8

Bobba, M., \& Coviello, D. (2007). Weak instruments and weak identification, in estimating the effects of education, on democracy. Economics Letters, 96(3), 301-306. https://doi.org/10.1016/j.econlet.2007.01.018

Bun, M. J. G., \& Windmeijer, F. (2009). The weak instrument problem of the system GMM estimator in dynamic panel data models. Econometrics Journal, 12, 1-32. https://doi.org/10.2139/ssrn.1486048 
Drukker, D. M. (2008). Econometric analysis of dynamic panel-data models using Stata.Summer North American Stata Users Group meeting. Retrieved from http://repec.org/snasug08/drukker_xtdpd.pdf

Hanushek, E. A., \& Wößmann, L. (2010). Education and Economic Growth. In P. Peterson, E. Baker, \& B. McGaw (Eds.), International Encyclopedia of Education (Vol. 2, pp. 245-252). https://doi.org/10.1016/B978-0-08-044894-7.01227-6

Hanushek, E., \& Kimko, D. (2000). Schooling, Labor Force Quality, and the Growth of Nations. American Economic Review, 90(5), 1184-1208. https://doi.org/10.1257/aer.90.5.1184

Hayakawa, K. (2007). Small Sample Bias Properties of the System GMM Estimator in Dynami Panel Data Models. Economic Letters, 95(1), 32-38. https://doi.org/10.1016/j.econlet.2006.09.011

Jamison, D. T., Hanushek, E. A., Jamison, E. A., \& L. Woessmann (2008). Education and economic growth. Education Next, 8(2).

Keller, K. R. I. (2006). Investment in primary, secondary, and higher education and th effects on economic growth. Contemporary Economic Policy, 24(1), 18-34. https://doi.org/10.1093/cep/byj012

Klenow, P., \& Rodriguez-Clare, A. (2005). Externalities and growth, chp.11. In P. Aghion, \& S. N. Durlauf (Eds.), Handbook of Economics Growth 1A. https://doi.org/10.1016/S1574-0684(05)01011-7

Krueger, A. B., \& Lindahl, M. (2001). Education for growth: Why and for whom? Journal of Economic Literature, 39(4), 1101-36. https://doi.org/10.1257/jel.39.4.1101

Lucas, R. E. (1988). On the mechanics of economic development. Journal of Monetary Economics, 22(1), 3-42. https://doi.org/10.1016/0304-3932(88)90168-7

Mankiw, G. N. (2007). Principles of microeconomics (4th ed.). Mason, USA: Thomson South-Western Publisher.

McMahon, W. W. (2002). Education and Development: Measuring the Social Benefits. UK: Oxford University Press.

McMahon, W. W. (2010). The external benefits of education. In D. J. Brewer, \& P. McEwan (Eds.), The Economics of Education, Elsevier. https://doi.org/10.1016/B978-0-08-044894-7.01226-4

McMahon, W. W., \& Oketch, M. (2013). Education's Effects on Life's Chances and on Development: An $\begin{array}{lllll}\text { Overview. British Journal of Educational } & \text { Studies, } & 61(1), & \text { 79-107. }\end{array}$ https://doi.org/10.1080/00071005.2012.756170

Mincer, J. (1974). Schooling, Experience, and Earnings. Nat. Bur. of Economic Research, New York.

Ozturk, I. (2001). The role of education in economic development: A theoretical perspective. Journal of Rural Development and Administration, XXXIII(1), 39-47.

Petrakis, P. E., \& Stamatakis, D. (2002). Growth and educational levels: A comparative analysis. Economics of Education Review, 21(2), 513-521. https://doi.org/10.1016/S0272-7757(01)00050-4

Psacharopoulos, G., \& Maureen, W. (1985). Education for development.: An analysis of investment choices. Oxford: Oxford University Press.

Romer, P. M. (1990). Endogenous technological change. The Journal of Political Economy, 98(5), S71-S102. https://doi.org/10.1086/261725

Schultz, T. P. (1999). Health and schooling investment in Africa. The Journal of Economics Perspectives, 13(3), 67-88. https://doi.org/10.1257/jep.13.3.67

Schultz, T. W. (1961). Investment in human Capital, American Economic Review, 51(1), 1-17.

World Bank. (2017). World Development Indicators and Global Development Finance for various years. World DataBank, The World Bank Group. Retrieved from http://ddp-ext.worldbank.org/ext/DDPQQ/member.do?method=getMembers\&userid=1\&queryID=6

\section{Copyrights}

Copyright for this article is retained by the author(s), with first publication rights granted to the journal.

This is an open-access article distributed under the terms and conditions of the Creative Commons Attribution license (http://creativecommons.org/licenses/by/4.0/). 